\title{
IMPLIKASI TEORI AKUNTANSI POSITIF DAN TEORI KEAGENAN DALAM PRAKTIK MANAJEMEN LABA
}

\author{
Suripto $^{1 *}$, Supriyanto ${ }^{2}$ \\ 1,2 Jurusan Administrasi Bisnis Fakultas Ilmu Sosial dan Ilmu Politik Universitas Lampung \\ *Email Penulis korespondensi: suriptob.1969@fisip.unila.ac.id
}

\begin{abstract}
Abstrak
Tujuan penelitian ini untuk menguji teori akuntansi positif dengan menganalisis pengaruh komite audit, komisaris Independen terhadap manajemen laba melalui pengujian hipotesis utang, motivasi bonus terhadapa manajemen llaba, dengan menambahkan variable ukuran perusahaan sebagai variabel kontrol terhadap manajemen laba pada perusahaan perbankan yang terdaftar di Bursa Efek Indonesia 2015-2020. Teknik sampling yang digunakan adalah purposive sampling dengan analisis data model regresi informasi. Hasil penelitian menegaskan bahwa komisaris independen secara parsial memiliki pengaruh signifikan terhadap manajemen laba. Komite audit memiliki berpengaruh signifikan terhadap manajemen Laba dan motivasi bonus tidak berpengaruh terhadap manajemen laba serta motivasi utang tidak berpengaruh terhadap manajemen laba. Sedangkan variabel ukuran perusahaan tidak berpengaruh terhadap manajemen laba. Secara simultan komisaris independen, komite audit, motivasi bonus, motivasi hutang dan ukuran perusahaan berpengaruh signifikan terhadap manajemen laba. Temuan ini ini menunjukkan bahwa bahwa motivasi yang dikembangkan dalam teori akuntansi positif tidak relevan dalam manajemen laba.
\end{abstract}

Kata kunci: Komisaris independen, komite audit, motivasi bonus, motivasi utang, ukuran perusahaan dan manajemen laba.

\begin{abstract}
The purpose of this study is to test positive accounting theory by analyzing the effect of audit committees, independent commissioners on earnings management through debt hyphothesis testing, bonus motivation on earnings management, by adding the firm size variable as a control variable on earnings management in banking companies listed on the Indonesia Stock Exchange 2015-2020. The results of the study confirm that the independent commissioners partially have a significant influence on earnings management. The audit committee has a significant effect on earnings management and bonus motivation has no effect on earnings management and debt motivation has no effect on earnings management. While the firm size variable has no effect on earnings management. Simultaneously independent commissioners, audit committee, bonus motivation, and firm size have a significant effect on earnings management. This findings indicates that the motivation developed in positive accounting theory in earnings management.
\end{abstract}

Keyword: Independent commissioners, audit committee, bonus motivation, debt motivation, firm size, and earnings management. 


\section{Paradigma: Jurnal Masalah Sosial, Politik,}

dan Kebijakan

http://jurnal.upnyk.ac.id/index.php/paradigma/index P-ISSN: 1410-3133. E-ISSN: $x x x x-x x x x$

\section{Pendahuluan}

Keberhasilan dalam mengambil keputusan tergantung pada keakuratan informasi atau kebenaran data. Data yang diolah akan menjadi informasi yang sesuai dengan kebutuhan dalam pengambilan keputusan. Informasi yang seharusnya terkait dengan bisnis harus mencerminkan kenyataan yang sebenarnya. Artinya informasi adalah gambaran dunia nyata atau fenomena yang sebenarnya. Di sini ada dua hal yang harus diperhatikan yaitu kesesuianan informasi dengan realita yang sebenarnya. Ini semuanya akan tercermin dalam laporan keuangan sehingga laporan keuangan harus relevan dengan realita. Kesesuaian ini dalam membuat laporan keuangan di kenal dengan managemen laba.

Semua informasi tentang badan usaha tercermin dalam laporan keuangan. Laporan keuangan harus dapat mencerminkan semua peristiwa operasional bisnis. Laporan keuangan merupakan sumber informasi bagi para pemangku kepentingan untuk mengambil keputusan. Informasi tentang suatu bisnis dapat menjadi tidak valid, sehingga kebenaran keputusan yang dibuat oleh pemangku kepentingan diragukan, atau dengan kata lain, keakuratan keputusan pemangku kepentingan ditentukan oleh kebenaran informasi yang mereka terima sehingga jika dasar yang digunakan salah, keputusan mereka buat akan salah. Berarti informasi tersebut menyesatkan bagi penggunanya. Laba adalah salah satu bagian dari informasi yang mencerminkan kinerja bisnis. Begitu pentingnya profit bagi sebuah bisnis karena profit merupakan cermin dari nilai perusahaan dari keberadaan sebuah bisnis. Permasalahan bagaimana prosesnya, atau pengolahan datanya sehingga menjadi informasi yang valid sangat tergantung dari managemen laba yang dilakukan perusahaan. Besar kecilnya keuntungan tergantung pada proses dan prosedur pengolahan data dan pemilihan proses dan prosedur tergantung siapa yang melakukan pengolahan. Proses dan prosedur tidak tunggal, banyak pilihan. Pemilihan prosedur sangat berkaitan dengan siapa yang membuat informasi. Keadaan seperti ini yang memungkinkan informasi menjadi tidak valid, sangat tergantung pada kepentingan pembuatnya. Laba sebagai informasi sangat mungkin untuk tidak menggambarkan kebenaran, tetapi mengikuti kepentingan siapa yang memberikan informasi tersebut. Informasi bukanlah apa adanya, tetapi apa yang ada di balik informasi tersebut, apa kepentingannya. Mengenai laba, pertanyaannya adalah siapa yang berkepentingan dengan laba tersebut yang dikenal dengan istilah manajemen laba (Suripto, 2021b; Suripto, 2021a).

Alasan inilah mengapa manajemen laba menjadi masalah yang harus diselesaikan. Dua perspektif penting yang dapat digunakan untuk menjelaskan mengapa manajemen laba dilakukan oleh seorang manajer, yaitu perspektif informasi dan perspektif oportunis. Perspektif informasi adalah pandangan yang menyatakan bahwa manajemen laba adalah kebijakan manajerial untuk mengungkapkan harapan manajer tentang arus kas masa depan perusahaan. 


\section{Paradigma: Jurnal Masalah Sosial, Politik, dan Kebijakan \\ http://jurnal.upnyk.ac.id/index.php/paradigma/index P-ISSN: 1410-3133. E-ISSN: xxxx-xxxx}

Kedua perspektif tersebut memiliki hubungan kausal yang mendorong terjadinya manajemen laba.

Krisis kredit di sektor perbankan telah menjadi fokus sistem tata kelola dan pengawasan dalam manajemen risiko di industri perbankan Malaysia. Penelitian ini mengkaji beberapa elemen penting dari tata kelola perusahaan. Berdasarkan hasil analisis regresi menunjukkan bahwa hanya manajemen risiko yang berdampak pada kecurangan, tetapi di sisi lain, tata kelola perusahaan merugikan kecurangan atau kesalahan karyawan. Hasil penelitian ini menunjukkan bahwa tata kelola perbankan tidak mampu mengurangi kejadian fraud atau manajemen laba (Rahman \& Anwar, 2014; Suryani \& Rofida, 2020; Supriyanto et al., 2021).

Tata Kelola Perusahaan yang baik tumbuh sejalan dengan tuntutan masyarakat akan kehidupan bisnis yang sehat, bersih, dan bertanggung jawab. Tuntutan ini merupakan jawaban publik atas meningkatnya kasus penyimpangan korporasi di seluruh dunia. Selain itu, tuntutan ini juga mencerminkan kebingungan masyarakat mengapa kasus penyimpangan korporasi bisa terjadi di mana saja. Publik juga bertanya-tanya mengapa penyimpangan perusahaan seolah menjadi ajang konspirasi semua pihak yang terkait dengan perusahaan. Publik juga mempertanyakan mengapa kasus penyimpangan tersebut semakin marak seiring dengan penerapan dan praktik konsep manajemen modern dalam pengelolaan dunia usaha. Tata kelola perusahaan yang baik pada dasarnya adalah pedoman, aturan main yang menjamin keselarasan kepentingan antar pemangku kepentingan. Untuk menjamin tercapainya semua kepentingan tersebut, diperlukan tata kelola yang baik (Sulistyanto, 2014; Assagaf dkk., 2020).

Prinsip-prinsip yang terkandung dalam good corporate governance atau tata kelola yang baik dapat berjalan dengan efektif, sehingga diperlukan sistem pengawasan dan pengendalian yang memadai. Untuk itu perlu dibangun sistem pengawasan dan pengendalian yang sesuai dengan ketentuan yang berlaku untuk menciptakan kehidupan usaha yang bersih, sehat, dan bertanggung jawab, untuk menjamin keselarasan kepentingan. Prinsip-prinsip yang terkandung dalam good corporate governance atau tata kelola yang baik dapat berjalan dengan efektif, sehingga diperlukan sistem pengawasan dan pengendalian yang memadai. Untuk itu perlu dibentuk sistem pengawasan dan pengendalian yang sesuai dengan ketentuan yang berlaku untuk mewujudkan lingkungan yang bersih, kehidupan usaha yang sehat, dan bertanggung jawab, sehingga terjamin keselarasan kepentingan. Prinsip-prinsip yang terkandung dalam good corporate governance atau tata kelola yang baik dapat berjalan dengan efektif, sehingga diperlukan sistem pengawasan dan pengendalian yang memadai. Untuk itu perlu dibangun sistem pengawasan dan pengendalian yang mengikuti ketentuan yang berlaku untuk mewujudkan kehidupan usaha yang bersih, sehat, dan bertanggung jawab, sehingga terjamin keselarasan kepentingan (Heriningsih, 2014) . 


\section{Paradigma: Jurnal Masalah Sosial, Politik, dan Kebijakan \\ http://jurnal.upnyk.ac.id/index.php/paradigma/index P-ISSN: 1410-3133. E-ISSN: xxxx-xxxx}

Menganalisis pengaruh tata kelola perusahaan dan struktur kepemilikan terhadap manajemen laba di Bursa Efek Karachi 2003-2010. Hasil penelitian menunjukkan bahwa bentuk kepemilikan menentukan manajemen pendapatan, yang berarti bahwa manajer dapat mempengaruhi keputusan perusahaan untuk mewujudkan kepentingannya. Pencarian lebih lanjut tetap biasa dilakukan dengan penelitian sebelumnya, di mana dewan pengurus sangat dominan dalam mengawasi pemegang saham minoritas, sementara pembeli luar memiliki pengaruh luas dalam membatasi manajemen laba. Sebaliknya, dewan direksi, ukuran auditor perusahaan, dan perhatian kepemilikan tidak memiliki dampak besar pada manajemen pendapatan. Beberapa variabel kontrol memiliki fungsi dalam menentukan manajemen laba, termasuk profitabilitas, pertumbuhan, dan leverage.

Perbedaan kepentingan antara investor dan agen atau manajer akan menimbulkan konflik kepentingan antara investor dan manajer. Untuk menyelaraskan kepentingan tersebut, diperlukan tata kelola yang baik, termasuk manajer atau perusahaan yang harus diawasi dan dikendalikan. Pengawasan dan pengendalian dapat terlaksana dengan baik jika dilakukan oleh orang-orang yang memiliki kemandirian. Semua tindakan dan keputusan yang dia buat harus terlepas dari kepentingan manajer. Untuk membangun sistem pengawasan dan pengendalian yang efektif dalam suatu perusahaan, diperlukan dua pihak, yaitu komite audit dan komisaris independen. Pada prinsipnya wewenang dan tanggung jawab mempunyai tujuan yang sama yaitu menciptakan kehidupan usaha yang sehat, bersih dan bertanggung jawab yang pada akhirnya mencapai kepentingan bersama (Widarjono, 2013; Wijayanti \& Yandra, 2020).

Penelitian yang menguji pengaruh corporate governance terhadap kinerja di sektor perbankan di Nigeria. Proksi corporate governance dalam penelitian ini menggunakan ukuran dewan direksi dan audit bersaing, sedangkan kinerja menggunakan proksi return on assets (ROA). Hasil penelitian menunjukkan bahwa ukuran dewan direksi berpengaruh negatif signifikan terhadap kinerja perbankan, sedangkan komet audit berpengaruh negatif signifikan. Hasil penelitian menunjukkan bahwa corporate governance memiliki peran penting dalam meningkatkan kinerja keuangan. Penelitian ini sejalan dengan Agency Theory, dimana corporate governance dapat menyelaraskan kepentingan prinsipal dan agen (Ado et al., 2017).

Manajer harus memenuhi kepentingan investor yaitu meningkatkan nilai perusahaan dan kesejahteraan pemilik. Sebaliknya dan berhak menerima penghargaan atas apa yang telah dilakukannya. Sedangkan pemilik perusahaan harus memberikan penghargaan kepada manajer perusahaan karena telah bekerja untuk meningkatkan nilai dan kesejahteraan perusahaan. Masing-masing pihak hanya berusaha memaksimalkan kepentingannya dengan mengorbankan kepentingan pihak lain (Miswanto dkk., 2020).

Motivasi tersebut mempengaruhi pola rekayasa manajerial yang dilakukan oleh manajer perusahaan. Artinya bagaimana pola rekayasa ini tergantung pada apa yang ingin dicapai oleh 


\section{Paradigma: Jurnal Masalah Sosial, Politik, dan Kebijakan \\ http://jurnal.upnyk.ac.id/index.php/paradigma/index P-ISSN: 1410-3133. E-ISSN: xxxx-xxxx}

manajer. Manajer dapat memanipulasi keuntungan mereka menjadi lebih besar atau lebih kecil dari keuntungan yang sebenarnya tergantung pada motivasi apa yang mendasari motivasi. Begitu juga jika manajer memanipulasi laba sehingga cenderung sama untuk beberapa periode. Secara umum, beberapa motivasi mendorong manajer untuk berperilaku oportunis, yaitu motivasi bonus, motivasi perjanjian utang, motivasi pajak, motivasi penjualan saham, motivasi pergantian direktur, dan motivasi politik. Pengelompokan ini sejalan dengan tiga hipotesis utama dalam teori akuntansi positif, Dasar pengembangan pengujian hipotesis untuk mendeteksi manajemen laba dalam Watts dan Zimmerman' Bukunya adalah hipotesis rencana bonus, hipotesis utang (ekuitas), dan hipotesis biaya politik. (Sulistyanto, 2014; Bertrand, 2003).

Tata Kelola Perusahaan erat kaitannya dengan praktik manajemen laba dalam suatu perusahaan. Komisaris independen dan komite audit, yang merupakan proksi dari tata kelola perusahaan, dapat digunakan untuk mengukur dan mengamati peluang manajemen pendapatan dalam suatu organisasi. Artinya good governance akan mengurangi praktik manajemen laba. Untuk menjamin terselenggaranya good governance sangat dipengaruhi oleh sejauh mana peran dewan pengawas dalam mengendalikan dan mengawasi perilaku manajer (Garcia, et al., 2009; Harris, et al., 2019; Huang, et al., 2016).

Perilaku manajer dalam praktik manajemen laba tidak hanya bergantung pada komisaris independen dan komite audit tetapi juga sangat dipengaruhi oleh motivasi bonus dan motivasi debt covenant dalam mengelola perusahaan. Dalam penelitian ini, penulis ingin mengetahui pengaruh corporate governance yang diproksikan oleh komisaris independen, komite audit, motivasi bonus, motivasi perjanjian utang, dan ukuran perusahaan sebagai variabel kontrol terhadap manajemen laba pada perusahaan perbankan di Indonesia yang sudah lama beredar di masyarakat. panjang BEI 2015-2020 yang beberapa penelitian sebelumnya memberikan hasil yang berbeda sehingga perlu dilakukan penelitian. Untuk memberikan hasil yang lebih akurat perlu ditambahkan variabel kontrol dengan model panel data tetap.

\section{Kajian Pustaka}

Teori pemangku kepentingan

Prinsip dasar dari teori pemangku kepentingan adalah bagaimana menyeleraskan kepentingan pihak-pihak yang terlibat dalam perusahaan. Usaha penyelarasan kepentingan ini diciptakan suatu tatakelola perusahaan. Kinerja keuangan merupakan salah satu tujuan dari perusahan, dengan kinerja keuangan yang baik diharapkan akan meningkatkan nilai perusahaan. Perusahaan modern lebih menekankan nilai perusahaan. Salah satu upaya penciptaan nilai melalui mekanisme Corporate governance selain sebagai kontrol sekaligus memberi rasa 


\section{Paradigma: Jurnal Masalah Sosial, Politik, dan Kebijakan \\ http://jurnal.upnyk.ac.id/index.php/paradigma/index P-ISSN: 1410-3133. E-ISSN: xxxx-xxxx}

percaya bagi pihak luar (investor) terhadap perusahaan). dari sebuah bisnis, dimana tata kelola dibangun agar sebuah bisnis dapat mencapai tujuannya.

Beberapan penelitian yang meneliti pengaruh tatakelola terhadap managemen laba (Latif \& Abdullah, 2015; Wardianto dkk., 2020). Laporan keuangan tahunan perusahaan diharapkan dapat menggambarkan posisi keuangan secara akurat, manajer akan berperan dalam menentukan manajemen laba sesuai dengan harapannya sehingga manajer akan mendapatkan insentif. Penelitian tersebut menggunakan proksi tatakelola dengan menggunakan tiga elemen corporate governance, yaitu: karakteristik dewan, karakteristik komite audit, dan struktur kepemilikan dalam menghambat manajemen laba. Penelitian ini dilakukan pada perusahaan non keuangan yang terdaftar di Bursa Efek Karachi periode 2003-2012. Temuan menunjukkan bahwa komite audit independen memiliki hubungan negatif dengan manajemen laba dan kepemilikan manajerial dan institusional memiliki hubungan positif dengan manajemen laba. Implikasi dari penelitian ini menunjukkan bahwa corporate governance sangat efektif dalam menghambat atau berpengaruh terhadap manajemen laba, artinya semakin baik karakteristik komite audit maka semakin kecil kemungkinan untuk melakukan manajemen laba.

Teori agensi

Ide keagenan adalah ide yang menggambarkan adanya hubungan antara yang esensial dengan agen atau disebut hubungan keagenan. Smith (1937) dalam karyanya The Wealth of Nations menjelaskan bahwa untuk sebuah organisasi yang dikelola oleh seorang individu atau kru yang bukan lagi pemiliknya, ada kemungkinan bahwa pria atau wanita atau kru sekarang tidak akan bekerja dalam mengejar pemiliknya (Panda \& Leepsa, 2017).

Terjadinya hubungan perusahaan adalah kontrak antara seorang pemimpin dan agen yang bekerja untuk memenuhi kepentingan mereka, memberikan dorongan untuk pertempuran perusahaan bisnis (Panda \& Leepsa, 2017). Dimana hubungan keagenan menimbulkan konflik kepentingan karena adanya inkonsistensi kepentingan antara agen dan prinsipal karena manajer tidak selalu bertindak untuk kepentingan pemilik (Messier et al., 2008). Teori keagenan dapat menerapkan mekanisme corporate governance untuk mengontrol semua tindakan agen dan menggantikan konflik keagenan di dalam perusahaan. (Panda \& Leepsa, 2017; Cohen et al., 2014)

Teori agensi menyediakan kerangka kerja yang menghubungkan pengungkapan emisi karbon dengan mekanisme tata kelola perusahaan. Menurut teori yang ada, mekanisme tata kelola perusahaan teratas dapat meningkatkan kapasitas perusahaan untuk menangani masalah saat ini dan membatasi konflik perusahaan (Haniffa \& Cooke, 2002; Mulyani dkk., 2019). Tidak hanya itu, prinsip organisasi memandang pelaporan emisi karbon sebagai jawaban untuk mengurangi asimetri fakta antara aktor dan agen (Salewski \& Zulch, 2014). 


\section{Paradigma: Jurnal Masalah Sosial, Politik,}

dan Kebijakan

http://jurnal.upnyk.ac.id/index.php/paradigma/index P-ISSN: 1410-3133. E-ISSN: Xxxx-Xxxx

Manajemen laba

Manajemen laba adalah pilihan kebijakan asuransi akuntansi yang dipilih oleh manajer atau tindakan nyata yang dapat mempengaruhi laba untuk mencapai tujuan pelaporan gaji tertentu (Scott, 2015: 455). Manajer dapat memilih kebijakan akuntansi yang mendukung pencapaian target positif dalam batas-batas yang ditetapkan oleh Prinsip Akuntansi yang Berlaku Umum (GAAP). GAAP fleksibel, memungkinkan administrasi untuk menggunakan kebijakan ini untuk mengajukan keuntungan nyata yang tidak lagi secara tepat mencerminkan prasyarat moneter perusahaan (Prior et al., 2008; Bao et al., 2017; Marchini et al., 2018; Murniati dkk., 2019; Adhikara, 2018).

Manajemen laba dari sudut pandang oportunistik dapat berusaha untuk menyediakan informasi yang seharusnya memberikan informasi yang salah kepada investor namun melindungi kinerja, reputasi, dan kompensasi manajer dalam perusahaan. Manajer yang terindikasi melakukan manajemen pendapatan berusaha untuk menutupi salah satu langkah ini melalui pengungkapan tanggung jawab sosial yang lebih tinggi dalam bentuk pengungkapan emisi karbon.Munculnya akuntabilitas sosial menciptakan gambaran bahwa perusahaan tersebut ramah lingkungan sehingga dapat memberikan bantuan yang lebih besar dari para pemangku kepentingan (Prior et al., 2008). Pemangku kepentingan akhirnya akan mengalihkan pengawasan dari indikasi pengelolaan gaji dengan kinerja tugas sosial perusahaan yang tepat dan inovatif.

Beberapan penelitian yang meneliti penyebab dilakukannya managemen laba dengan meneliti pengaruh komisaris independen, komete audit, motivasi bonus dan motivasi utang terhadap managemen laba (Latif \& Abdullah, 2015; Wardianto dkk., 2020; Sulistyanto, 2014; Bertrand, 2003; Garcia, et al., 2009; Harris, et al., 2019; Huang, et al., 2016).

\section{Metode}

Jenis penelitian ini termasuk dalam jenis penelitian kuantitatif. Dalam penelitian ini, populasinya adalah perusahaan perbankan yang telah go public di Bursa Efek Indonesia periode 2015-2020. Kriteria pemilihan sampel yang digunakan adalah perusahaan perbankan yang telah go public di Bursa Efek Indonesia yang secara konsisten menerbitkan dan melaporkan laporan tahunan dari tahun 2015-2020. Definisi Variabel:

1. Variabel bebas

Variabel independen dalam penelitian ini adalah Komisaris Independen, Komite Audit, Motivasi Bonus, Motivasi Perjanjian Hutang, dan Ukuran Perusahaan.

2. Variabel tak bebas

Variabel terikat dalam penelitian ini adalah manajemen laba 


\section{Paradigma: Jurnal Masalah Sosial, Politik,}

dan Kebijakan

http://jurnal.upnyk.ac.id/index.php/paradigma/index P-ISSN: 1410-3133. E-ISSN: Xxxx-Xxxx

Penelitian ini menggunakan teknik Purposive sampling yaitu teknik penentuan sampel dengan pertimbangan tertentu. Teknik ini dipilih agar mendapatkan informasi yang sesuai dengan variabel yang akan diteliti dengan difinisi operasional variabel sebagai berikut :

Tabel 1. Informasi Variabel dengan Definisi Operasional Variabel

\begin{tabular}{|c|c|c|}
\hline Variabel & Definisi & Pengukuran \\
\hline $\begin{array}{l}\text { Komisaris } \\
\text { Independen } \\
\text { (X1) }\end{array}$ & $\begin{array}{l}\text { dewan komisaris diberi } \\
\text { tanggung jawab atas } \\
\text { pengawasan kualitas } \\
\text { informasi yang terkandung } \\
\text { dalam laporan keuangan }\end{array}$ & $K I=\frac{\text { Total dewan komisaris }}{\text { Total ang gota dewan komisaris }}$ \\
\hline $\begin{array}{l}\text { Komite } \\
\text { Audit } \\
\text { (X2) }\end{array}$ & $\begin{array}{l}\text { komite audit dapat } \\
\text { membantu dewan } \\
\text { komisaris dalam } \\
\text { pelaksanaan tugas } \\
\text { mengawasi proses } \\
\text { pelaporan keuangan }\end{array}$ & $K A=J u m l a h$ komite audit \\
\hline $\begin{array}{l}\text { Motivasi } \\
\text { Bonus } \\
\text { (X3) }\end{array}$ & $\begin{array}{l}\text { Agar bisa mencapai } \\
\text { tingkat kinerja yang } \\
\text { memberikan bonus, } \\
\text { manajer dapat } \\
\text { memperbesar atau } \\
\text { memperkecil angka-angka } \\
\text { dalam laporan keuangan } \\
\text { sehingga bonus itu selalu } \\
\text { didapatkannya setiap tahun }\end{array}$ & Bonus $=$ Jumlah Bonus \\
\hline $\begin{array}{l}\text { Motivasi } \\
\text { Utang } \\
(\mathrm{X} 4)\end{array}$ & $\begin{array}{l}\text { Pada perusahaan yang } \\
\text { memiliki perjanjian hutang } \\
\text { yang tinggi maka manajer } \\
\text { perusahaan cenderung } \\
\text { menggunakan metode } \\
\text { akuntansi yang dapat } \\
\text { meningkatkan pendapatan } \\
\text { laba }\end{array}$ & $P H=\frac{\text { Total Hutang }}{\text { Total Ekuitas }}$ \\
\hline $\begin{array}{l}\text { Ukuran } \\
\text { Perusahaan } \\
\text { (X5) }\end{array}$ & $\begin{array}{l}\text { Ukuran yang digunakan } \\
\text { untuk mengetahui apakah } \\
\text { perusahaan memiliki } \\
\text { aktivitas operasional yang } \\
\text { lebih kompleks sehingga }\end{array}$ & $\begin{array}{c}\text { Ukuran Perusahaann }=\text { jumlah saham yang } \\
\text { beredar diakhir tahun X harga saham } \\
\text { penutupan akhir tahun }\end{array}$ \\
\hline
\end{tabular}


Paradigma: Jurnal Masalah Sosial, Politik, dan Kebijakan

http://jurnal.upnyk.ac.id/index.php/paradigma/index P-ISSN: 1410-3133. E-ISSN: xxxx-xxxx

\begin{tabular}{|l|l|c|}
\hline \multicolumn{1}{|c|}{ Variabel } & \multicolumn{1}{|c|}{ Definisi } & \multicolumn{1}{c|}{ Pengukuran } \\
\hline & $\begin{array}{l}\text { dimungkinkan melakukan } \\
\text { manajemen laba }\end{array}$ & \\
\hline $\begin{array}{l}\text { Manajemen } \\
\text { Laba }\end{array}$ & $\begin{array}{l}\text { Campur tangan dalam } \\
\text { proses penyusunan } \\
\text { pelaporan keuangan } \\
\text { eksternal, dengan tujuan } \\
\text { untuk memperoleh } \\
\text { keuntungan pribadi }\end{array}$ & $\begin{array}{c}\text { Discretionary Accruals }=\text { Total Accruals }- \text { Non } \\
\text { Discretionary Accruals }\end{array}$ \\
\hline
\end{tabular}

Sumber: Data Primer tahun 2021

Analisis Regresi Berganda Model Data Panel Analisis regresi linier berganda dalam penelitian ini digunakan untuk mengetahui pengaruh komisaris independen, komite audit, motivasi bonus, motivasi debt covenant, dan ukuran perusahaan terhadap manajemen laba pada perusahaan perbankan yang telah go public di BEI untuk periode 2015 hingga 2020.

Berikut model regresi dalam penelitian ini (Ghozali, 2005), yaitu:

$$
\mathrm{Y}=\alpha+\beta 1 \mathrm{KI}+\beta 2 \mathrm{KA}+\beta 3 \mathrm{MB}+\beta 4 \mathrm{MPH}+\beta 5 \mathrm{UP}+\mathrm{e} .
$$

Keterangan :

Y : Manajemen Laba

$\alpha \quad$ : Konstanta

$\beta 1$ : Koefisien KI (Komisaris Independen)

$\beta 2$ : Koefisien KA (Komite Audit)

$\beta 3$ : Koefisien MB (Motivasi Bonus)

$\beta 4$ : Koefisien MPH (Motivasi Utang)

$\beta 5$ : Koefisien UP (Ukuran Perusahaan)

e : Error term (tingkat kesalahan penduga dalam penelitian

Pemilihan Model

Untuk memilih model yang tepat dapat dilakukan beberapa pengujian yaitu dengan menggunakan Uji Hausman dan Uji Efek Tetap, Uji F atau Uji Chow. Sebuah. Uji Hausman digunakan untuk memilih model efek tetap atau efek acak.. Uji efek tetap Uji F atau uji chow digunakan untuk memilih apakah manekin yang akan digunakan merupakan efek yang sering atau acak.. Chow-test (Umum vs Efek Tetap). Tes Chow digunakan untuk memutuskan dampak yang sering atau tetap yang akan digunakan dalam perkiraan. 


\section{Paradigma: Jurnal Masalah Sosial, Politik,}

dan Kebijakan

http://jurnal.upnyk.ac.id/index.php/paradigma/index P-ISSN: 1410-3133. E-ISSN: $x x x x-x x x x$

\section{Hasil dan Pembahasan}

Pengolahan data dengan regresi data panel menggunakan tiga alternatif metode, yaitu metode pooled least rectangle/common effect, metode fixed impact, dan pendekatan random impact. Yang harus dilakukan setelah mengestimasi ketiga metode (pooled least square, fixed effect, dan random effect) adalah menguji metode mana yang paling tepat untuk digunakan. Pengujian dilakukan dalam tiga tahap, yaitu uji $\mathrm{F}$ atau uji chow dan uji Hausman. Untuk pengujian pertama, uji chow dilakukan untuk menentukan antara metode pooled least square dan metode fixed-effect. Metode pooled least square sebelum menguji model.

Tabel 2. Pooled Least Square atau Hasil Umum

\begin{tabular}{|c|c|c|c|c|}
\hline Variabel & Koefisien & $\begin{array}{l}\text { Std. } \\
\text { Kesalahan }\end{array}$ & $\begin{array}{l}\mathrm{t}- \\
\text { Statistik }\end{array}$ & Masalah. \\
\hline $\mathrm{C}$ & 14.21788 & 1.763939 & 8.060299 & 0,0000 \\
\hline $\mathrm{X} 1 ?$ & 0.176089 & 0.275568 & 0.639004 & 0,5246 \\
\hline $\mathrm{X} 2 ?$ & $-0,149647$ & 0.200813 & 0.745206 & 0,4582 \\
\hline $\mathrm{X} 3 ?$ & 0.122430 & 0,156162 & 0,783990 & 0,4353 \\
\hline $\mathrm{X} 4 ?$ & $-0,019621$ & 0,018551 & $\overline{-}-057713$ & 0.2932 \\
\hline $\mathrm{X} 5 ?$ & -0.030835 & 0,049225 & $-\overline{0.626406}$ & 0,5327 \\
\hline R-kuadrat & 0,025718 & \multicolumn{2}{|c|}{$\begin{array}{l}\text { Rata-rata tergantung } \\
\text { var }\end{array}$} & 14.68149 \\
\hline $\begin{array}{l}\text { Disesuaikan R- } \\
\text { kuadrat }\end{array}$ & -0.032275 & \multicolumn{2}{|c|}{ tergantung SD } & 1,880437 \\
\hline F-statistik & 0,443472 & \multirow{2}{*}{\multicolumn{2}{|c|}{$\begin{array}{l}\text { Statistik Durbin- } \\
\text { Watson }\end{array}$}} & 1.004201 \\
\hline Prob (F-statistik) & 0,816879 & & & \\
\hline
\end{tabular}

Sumber: Data Primer tahun 2021

Tabel 3. Hasil Tes Chow

\begin{tabular}{llll}
\hline Uji penampang efek tetap & & & \\
\hline Uji Efek & Statistik & df & Masalah. \\
$\begin{array}{l}\text { Penampang melintang F } \\
\begin{array}{l}\text { Penampang melintang } \\
\text { chi-kuadrat }\end{array}\end{array}$ & 7.806144 & $(14.70)$ & 0,0000 \\
\hline
\end{tabular}

Sumber: Data Primer tahun 2021 
Paradigma: Jurnal Masalah Sosial, Politik, dan Kebijakan

http://jurnal.upnyk.ac.id/index.php/paradigma/index P-ISSN: 1410-3133. E-ISSN: Xxxx-Xxxx

\section{Tabel 4. Hasil Tes Hausman}

\begin{tabular}{llll}
\hline \multicolumn{2}{l}{ Uji efek acak penampang } & & \\
\hline Ringkasan Tes & Chi-Sq. Statistik & Chi-Sq. df & Masalah. \\
Penampang acak & 6,862456 & 5 & 0.2311 \\
\hline
\end{tabular}

Sumber: Data Primer tahun 2021

Tabel 5. Hasil Efek Acak

\begin{tabular}{crrrr}
\hline Variabel & Koefisien & $\begin{array}{r}\text { Std. } \\
\text { Kesalahan }\end{array}$ & $\begin{array}{r}\text { t- } \\
\text { Statistik }\end{array}$ & Masalah. \\
\hline C & 17.47798 & 2.824188 & 6.188674 & 0,0000 \\
X1? & 0.591418 & 0.313950 & 2.883794 & 0,0031 \\
X2? & 0,064866 & 0.200327 & 2.323801 & 0,0469 \\
X3? & $-0,213149$ & 0.227500 & - & 0.3515 \\
& & & 0.936916 & \\
X4? & -0.013160 & 0,013848 & - & 0.3447 \\
& & & 0.950328 & \\
X5? & 0,059791 & 0,07164 & 0.830850 & 0,4084 \\
\hline
\end{tabular}

Sumber: Data Primer tahun 2021

Berdasarkan hasil regresi linier lebih dari satu output model random impact menggunakan Eviews 9 menunjukkan nilai steady sebesar 17,47798, sedangkan nilai koefisien variabel Komisaris Independen menunjukkan harga sebesar 0,591418, variabel Komite Audit menunjukkan nilai koefisien sebesar 0,064866, variabel motivasi. Bonus tersebut menunjukkan koefisien fee sebesar -0,213149, variabel Motivasi Perjanjian Hutang menunjukkan koefisien fee sebesar -0,013160 dan variabel Ukuran Perusahaan menunjukkan koefisien fee sebesar 0,059791. terutama berdasarkan koefisien angka di atas model pencarian yang dapat dibentuk dengan menggunakan beberapa analisis regresi linier adalah sebagai berikut:

$$
\mathrm{ML}=17.47798+0.591418 \mathrm{KI}+0.064866 \mathrm{KA}-0.213149 \mathrm{MB}-0.013160 \mathrm{MPH}+0.059791 \mathrm{UP}
$$

Dari persamaan regresi di atas dapat dijelaskan bahwa konsistensi sebesar 17.47798 menunjukkan besarnya Manajemen Laba jika Komisaris Independen, Komite Audit, Motivasi Bonus, Motivasi Perjanjian Hutang, dan Ukuran Perusahaan sama dengan nol. Nilai konstanta adalah 17.47798; sedangkan koefisien variable 0,591418; 0,064866; -0,213149; -0.013160; 0,059791 untuk setiap perusahaan yang dibandingkan baik secara berurutan maupun acak. Misal selisih nilai konstanta BBRI dengan BBTN adalah 1,047402 + $(-0,826801)=0,220601$, selisih nilainya adalah 0,220601, dapat dijelaskan bahwa jika BBRI memiliki utang sebesar 0,220601 yang harus dibayarkan kepada BBTN, maka nilai tersebut akan menjadi keuntungan terhadap BBTN. 


\section{Paradigma: Jurnal Masalah Sosial, Politik, dan Kebijakan \\ http://jurnal.upnyk.ac.id/index.php/paradigma/index P-ISSN: 1410-3133. E-ISSN: Xxxx-Xxxx}

Nilai regresi variabel Komisaris Independen memiliki nilai sebesar 0,591418, artinya setiap kenaikan satu persen pada Komisaris Independen akan menghasilkan peningkatan pada variabel Manajemen Laba sebesar 0,591418\%. Sebaliknya, setiap penurunan satu persen pada Komisaris Independen akan menyebabkan penurunan variabel Manajemen Laba sebesar 0,591418\%. Nilai regresi variabel Komite Audit memiliki nilai sebesar 0,064866 artinya setiap kenaikan satu persen Komite Audit akan mengakibatkan peningkatan variabel Manajemen Laba sebesar 0,064866\%. Sebaliknya, setiap penurunan satu persen Komite Audit akan menyebabkan penurunan variabel Manajemen Laba sebesar 0,064866\%.

Nilai regresi variabel Motivasi Bonus memiliki nilai sebesar -0,213149, artinya setiap kenaikan satu persen pada Motivasi Bonus akan mengakibatkan penurunan variabel Manajemen Laba sebesar -0,213149\%. Sebaliknya, setiap batas satu persen dalam Motivasi Bonus akan mendorong peningkatan pada variabel Manajemen Laba dengan menggunakan 0,213149\%. Harga regresi variabel Motivasi Perjanjian Hutang memiliki fee sebesar 0,013160, dimana setiap peningkatan Motivasi Perjanjian Hutang akan menghasilkan batasan pada variabel Manajemen Laba sebesar -0,013160\%. Sebaliknya, setiap penurunan dalam Motivasi Perjanjian Hutang akan mendorong peningkatan pada variabel Manajemen Laba dengan memanfaatkan $-0,013160 \%$. Biaya regresi variabel ukuran perusahaan memiliki harga sebesar 0,059791,

Variabel manajemen dengan menggunakan 0,059791\%. Sebaliknya, setiap pengurangan satu persen dalam Ukuran Perusahaan akan menyebabkan batasan pada variabel Manajemen Laba hingga 0,059791\%.

Tabel 6. Hasil Perhitungan Uji F

\begin{tabular}{llllll}
\hline $\begin{array}{l}\text { Variabel yang dicari } \\
\text { korelasinya }\end{array}$ & Akun & Tabel & Masalah & Keterangan \\
\hline $\begin{array}{l}\text { Pengaruh X1, X2, X3, X4 } \\
\text { dan X5 terhadap Y }\end{array}$ & 8,080259 & 2.32 & 0,000000 & Ha. diterima \\
\hline
\end{tabular}

Sumber: Data Primer tahun 2021

Berdasarkan hasil uji $\mathrm{F}$ diperoleh nilai peluang 0 dan Fhitung sebesar 8,080259, dengan $\mathrm{df} 1=(\mathrm{k}-1)=6-1=5$ dan $\mathrm{df} 2=(\mathrm{NK})=90-6=$ delapan puluh empat didapat a harga Ftabel 2 , 32. Biaya kemungkinan nol jauh lebih kecil dari 0,05 dan nilai Fhitung meningkat dari Ftabel $(8,080259>0,05)$. Dengan biaya probabilitas lebih kecil dari 0,05 dan biaya Fhitung lebih besar dari Ftabel, Ha6 diterima yaitu Komisaris Independen, Komite Audit, Motivasi Bonus, Motivasi Perjanjian Hutang, dan Ukuran Perusahaan secara bersamaan memiliki pengaruh ukuran penuh terhadap manajemen gaji di kelompok perbankan yang sudah lama go public. di BEI periode 2015-20202020. 
Tabel 7. Hasil perhitungan uji-t

\begin{tabular}{lllll}
\hline Variabel & Koefisien & $\begin{array}{l}\text { Std. } \\
\text { Kesalahan }\end{array}$ & t-Statistik & Masalah. \\
\hline C & 17.47798 & 2.824188 & 6.188674 & 0,0000 \\
X1 & 0.591418 & 0.313950 & 2.883794 & 0,0031 \\
X2 & 0,064866 & 0.200327 & 2.323801 & 0,0469 \\
X3 & $-0,213149$ & 0.227500 & -0.936916 & 0.3515 \\
X4 & -0.013160 & 0,013848 & -0.950328 & 0.3447 \\
X5 & 0,059791 & 0,07164 & 0.830850 & 0,4084 \\
\hline
\end{tabular}

Sumber: Data Primer tahun 2021

a. Berdasarkan tabel di atas dapat dilihat bahwa variabel Komisaris Independen berpengaruh signifiakan terhadap managemen laba. Hal ini mengindikasikan bahwab komisaris independen dapat berfungsi dengan baik dalam mengawasi prilaku managemen laba. Hal ini didukung oleh hasil penelitian oleh Latif \& Abdullah (2015) dan Wardianto dkk. (2020).

b. Variabel komite audit juga berpengaruh terhadap managemen laba. Komite audit sebagai badan yang memeriksa laporan keuangan dapat menjalankan perannya dalam menentukan managemen laba sebagaimana yang dihasilkan oleh Latif \& Abdullah (2015) dan Wardianto dkk. ( 2020).

c. Variabel Motivasi Bonus tidak berpengaruh signifikan terhadap manajemen laba berarti managemen laba dilakukan bukan karena ingin memperoleh bonus. Penelitian ini didukung oleh penelitian Charfeddine et al. (2013) dan Saftiana dkk. (2017).

d. Variabel Motivasi Perjanjian uutang tidak berpengaruh signifikan terhadap Manajemen Laba. Hal ini managemen laba dilkukan tidak untuk memperoleh utang sehingga laporan dibuat sedemikian rupa atau layak. Hasil ini sejalan denga hasil penelitian Charfeddine et al. (2013 dan Saftiana dkk. (2017).

e. Variabel Ukuran Perusahaan tidak perpengaruh terhadap manajemen laba sehingga besar kecilnya perusahaan tidak menentukan perusahaan malakukan managemen laba. Temuan ini sejalan dengan Charfeddine et al. (2013 dan Saftiana dkk. (2017).

Hasil analisis regresi data panel diperoleh interpretasi model regresi berganda sebagai berikut:

$\mathrm{ML}=17.47798+0.591418 \mathrm{KI}+0.064866 \mathrm{KA}-0.213149 \mathrm{MB}-0.013160 \mathrm{MPH}+0.059791$ UP

Interpretasi model regresi menunjukkan bahwa besarnya konstanta manajemen laba perusahaan, jika variabel Komisaris Independen (KI), Komite Audit (AC), Motivasi Bonus 


\section{Paradigma: Jurnal Masalah Sosial, Politik, dan Kebijakan \\ http://jurnal.upnyk.ac.id/index.php/paradigma/index P-ISSN: 1410-3133. E-ISSN: xxxx-xxxx}

(MB), Motivasi Perjanjian Hutang (MPH) dan Ukuran Perusahaan (UK) adalah sama ke nol, adalah 17, 47798. Jika terjadi peningkatan jumlah komisaris akan meningkatan manajemen laba sebesar 0,591418\%. Jika terjadi pemekaran komite audit sebanyak satu kali maka akan mengakibatkan terjadinya manajemen laba sebesar $0,064866 \%$. Jika ada satu kali peningkatan motivasi bonus, maka akan mengakibatkan batasan administrasi gaji sebesar 0,213149\%. Jika ada penguatan satu kali dalam motivasi untuk perjanjian utang, itu akan menghasilkan pengurangan administrasi pendapatan melalui 0,013160\%.

Angka R Square yang Disesuaikan adalah 0.604489. Hal ini menunjukkan bahwa hubungan variabel manajemen laba terhadap lima variabel independen yaitu Komisaris Independen (KI), Komite Audit (KA), Motivasi Bonus (MB), Motivasi Perjanjian Hutang (MPH), dan Ukuran Perusahaan (UK) memiliki hubungan hubungan kuat yang berarti 60,44\% dan dapat dijelaskan oleh variasi kelima variabel bebas.

Hasil uji t menunjukkan bahwa koefisien regresi variabel komisaris independen dan komite audit secara parsial berpengaruh baik terhadap manajemen gaji, sedangkan motivasi bonus, motivasi perjanjian hutang, dan ukuran perusahaan tidak berpengaruh signifikan terhadap manajemen laba (Charfeddine et al., 2013; Saftiana dkk., 2017)

Uji F model regresi menunjukkan bahwa 8,080259 > 0,05 maka $\mathrm{H}$ a6 diterima, dimana keterampilan Komisaris Independen, Motivasi Bonus Komite Audit, Motivasi Perjanjian Hutang, dan Ukuran Perusahaan secara bersama-sama memiliki pengaruh yang cukup besar terhadap Manajemen Laba pada perusahaan perbankan yang telah go public di BEI. 2015-2020. Artinya corporate governance berpengaruh terhadap manajemen laba. Hasil ini sejalan dengan penelitian (Pramithasari \& Yasa, 2016; Lin dkk., 2016; Ramachandran dkk., 2015; Kumaat, 2013; Latif \& Abdullah, 2015; Syah \& Syah, 2014; Ilyas dkk., 2018; Anglin et al., 2013; Notoatmodjo, 2014; Dia \& Yang, 2014; Gunarto dkk., 2020).

\section{Penutup}

Setelah menganalisis dan menguji hipotesis tentang pengaruh Komisaris Independen, Komite Audit, Motivasi Bonus, Motivasi Perjanjian Hutang dan Ukuran Perusahaan terhadap Manajemen Laba pada perusahaan perbankan yang telah go public di Bursa Efek Indonesia tahun 2015-2020, maka dapat ditarik kesimpulan sebagai berikut :

1. Komisaris independen memiliki pengaruh signifikan managemen laba

2. Komite audit memiliki pengaruh sigfnifikan terhadap managemen laba.

3. Motivasi bonus tidak berpengaruh terrhadap manajemen laba.

4. Motivasi perjanjian utang sebagian tidak berpengaruh terrhadap manajemen laba.

5. Secara parsial, ukuran perusahaan tidak berpengaruh terrhadap manajemen laba. 


\section{Paradigma: Jurnal Masalah Sosial, Politik, dan Kebijakan \\ http://jurnal.upnyk.ac.id/index.php/paradigma/index P-ISSN: 1410-3133. E-ISSN: Xxxx-Xxxx}

6. Komisaris independen, komite audit, motivasi bonus, motivasi utang, dan ukuran perusahaan berpengaruh signifikan terhadap Manajemen Laba.

\section{Daftar Pustaka}

Adhikara, ND (2018). Penerapan Standar Akuntansi Keuangan Bagi Badan Usaha Mikro, Kecil \& Menengah (SAK EMKM) dan Faktor-Faktor Yang Mempengaruhinya. JEMA: Jurnal Ilmiah Bidang Akuntansi Dan Manajemen, $15(2), \quad 50$. https://doi.org/10.31106/jema.v15i2.1126

Ado, A., Shafie, R., \& Goni, K. (2017). Tata kelola perusahaan sebagai mekanisme untuk mengukur kinerja keuangan bank di Nigeria. Jurnal Keuangan, Akuntansi, dan Manajemen, 8 (1), 1.

Anglin, P., Edelstein, R., Gao, Y., \& Tsang, D. (2013). Apa Hubungan Antara Tata Kelola REIT dan Manajemen Laba? Jurnal Keuangan dan Ekonomi Real Estat, 47 (3), 538563.https://doi.org/10.1007/s11146-012-9367-y

Assagaf, NA, Sukoharsono, EG, \& Baridwan, Z. (2020). Praktik Akuntansi di Era Keemasan Sultan Babullah: Kesultanan Ternate (1570-1583). Jurnal Dinamika Akuntansi Dan Bisnis, 7(2), 151-166. https://doi.org/10.24815/jdab.v7i2.16761

Bao, SR, \& Lewellyn, KB (2017). Struktur kepemilikan dan manajemen laba di pasar negara berkembang — Perspektif agensi yang dilembagakan. Tinjauan Bisnis Internasional, 26 (5), 828-838.https://doi.org/10.1016/j.ibusrev.2017.02.002

Bertrand, M., \& Schoar, A. (2003). Mengelola dengan gaya: Pengaruh manajer terhadap kebijakan perusahaan. Jurnal Ekonomi Triwulanan, 118 (4), 1169-1208. https://doi.org/10.1162/003355303322552775

Charfeddine, L., Riahi, R., \& Omri, A. (2013). Determinan Manajemen Laba di Negara Berkembang: Sebuah Studi dalam Konteks Tunisia. Jurnal Tata Kelola Perusahaan, 7 (1), 35-50.

Cohen, JR, Hoitash, U., Krishnamoorthy, G., \& Wright, AM (2014). Pengaruh keahlian industri laporan audit dalam menyatukan proses pelaporan. Tinjauan Akuntansi, 89 (1), 243273.https://doi.org/10.2308/accr-50585

Dia, L., \& Yang, R. (2014). Apakah Peraturan Industri Penting? Bukti Baru Komite Audit dan Manajemen Laba. Jurnal Etika Bisnis, 123 (4), 573-589.https://doi.org/10.1007/s10551013-2011-9

Garcia Lara, JM, Osma, BG, \& Neophytou, E. (2009). Kualitas laba di perusahaan ex-post gagal. Akuntansi dan Riset Bisnis, $39 \quad$ (2), 119-138. https://doi.org/10.1080/00014788.2009.9663353 


\section{Paradigma: Jurnal Masalah Sosial, Politik, dan Kebijakan \\ http://jurnal.upnyk.ac.id/index.php/paradigma/index P-ISSN: 1410-3133. E-ISSN: xxxx-xxxx}

Gunarto, T., Azhar, R., Tresiana, N., Supriyanto, \& Ahadiat, A. (2020). Akurat model perkiraan volatilitas untuk harga minyak mentah. Jurnal Internasional Ekonomi Energi dan Kebijakan, 10 (5), 228-233.https://doi.org/10.32479/ijeep.9513

Harris, O., Karl, JB, \& Lawrence, E. (2019). Kompensasi CEO dan manajemen pendapatan: Apakah gender benar-benar penting? Jurnal Penelitian Bisnis, 98, 1-14. https://doi.org/10.1016/j.jbusres.2019.01.013

Heriningsih, S. (2014). Kajian Empiris Tingkat Akuntabilitas Pemerintah Daerah dan Kinerja Penyelengara Pemerintah Daerah Terhadap Tingkat Korupsi Pada Kabupaten dan Kota di Indonesia. Paradigma: Jurnal Masalah Sosial, Politik Dan Kebijakan, 18(2), 29-40.

Huang, Z., \& Xue, Q. (2016). Pemeriksaan pengaruh struktur kepemilikan terhadap pelaporan keuangan: Bukti dari jaminan saham di Cina. Jurnal Riset Akuntansi China, 9 (2), 137152. https://doi.org/10.1016/j.cjar.2015.11.001

Ilyas, M., Ahmad, DA, Khan, MT, \& Khan, I. (2018). Dampak Tata Kelola Perusahaan pada Manajemen Laba: Bukti Empiris dari Pakistan. Jurnal Penelitian Ilmu Sosial, 6 (2), 2305-6533. https://doi.org/ISSN (E) 2306-112x

Kumaat, LC (2013). Tata Kelola Perusahaan dan Struktur Kepemilikan terhadap Manajemen Laba dan Kinerja Keuangan. Jurnal Keuangan dan Perbankan, 17 (1), 11-20.

Lin, Z., Liu, M., \& Noronha, C. (2016). Dampak Tata Kelola Perusahaan pada Manajemen Laba Informatif di Pasar Cina. Sempoa, 52 (3), 568-609.https://doi.org/10.1111/abac.12084

Marchini, PL, Mazza, T., \& Medioli, A. (2018). Dampak transaksi pihak berelasi pada manajemen laba: beberapa wawasan dari konteks Italia. Jurnal Manajemen dan Pemerintahan, 22 (4), 981-1014.https://doi.org/10.1007/s10997-018-9415-y

Miswanto, M., Arifin, R., \& Murniyati, D. (2020). Apakah komitmen kerja memediasi pengaruh etos kerja Islami terhadap kinerja dan keinginan berpindah? JEMA: Jurnal Ilmiah Bidang Akuntansi Dan Manajemen, 17(2), 169.https://doi.org/10.31106/jema.v17i2.5533

Mulyani, SR, Sari, MW, Sari, VN, \& Tawakalni, W. (2019). Pengaruh Locus of Control dan Budaya Organisasi Terhadap Kinerja Pegawai dengan Komitmen Organisasi sebagai Variabel Intervening. JEMA: Jurnal Ilmiah Bidang Akuntansi Dan Manajemen, 16(2), 147. https://doi.org/10.31106/jema.v16i2.2631

Murniati, M., Sa'diyah, M., \& Subadriyah, S. (2019). Hermeneutika manajemen laba: Antara tekanan dan peluang. JEMA: Jurnal Ilmiah Bidang Akuntansi Dan Manajemen, 16 (1), 46. https://doi.org/10.31106/jema.v16i1.1666

Pramithasari, AAPK, \& Yasa, GW (2016). Pengaruh good corporate governance terhadap manajemen laba pada perusahaan yang melakukan IPO. 6 (1), 3744.https://doi.org/10.14414/tiar.v6i1.565

Rahman, RA, \& Anwar, ISK (2014). Efektivitas Pencegahan Penipuan dan Teknik Deteksi di Bank Islam Malaysia. Procedia - Ilmu Sosial dan Perilaku, 145 (Februari), 97102.https://doi.org/10.1016/j.sbspro.2014.06.015 


\section{Paradigma: Jurnal Masalah Sosial, Politik, dan Kebijakan \\ http://jurnal.upnyk.ac.id/index.php/paradigma/index P-ISSN: 1410-3133. E-ISSN: xxxx-xxxx}

Ramachandran, J., Ngete, ZA, Subramanian, R., \& Sambasivan, M. (2015). Apakah tata kelola perusahaan mempengaruhi manajemen laba?: Bukti dari Singapura. Jurnal Daerah Berkembang, 49 (3), 263-274.https://doi.org/10.1353/jda.2015.0169

S. Latif, A., \& Abdullah, F. (2015). Efektivitas Tata Kelola Perusahaan dalam Membatasi Manajemen Laba di Pakistan. Jurnal Ekonomi Lahore, 20 (1), 135155.https://doi.org/10.35536/lje.2015.v20.i1.a5

Saftiana, Y., Mukhtaruddin, Putri, KW, \& Ferina, IS (2017). Kualitas Tata Kelola Perusahaan, Ukuran Perusahaan dan Manajemen Laba: Studi Empiris di Bursa Efek Indonesia. Manajemen Investasi dan Inovasi Keuangan, $14 \quad$ (4), 105 120.https://doi.org/10.21511/imfi.14(4).2017.10

Syah, K., \& Syah, A. (2014). Dampak Tata Kelola Perusahaan dan Struktur Kepemilikan pada Praktik Manajemen Laba: Bukti dari Perusahaan Tercatat di Pakistan. Jurnal Ekonomi Lahore, 19 (2), 27-70.https://doi.org/10.35536/lje.2014.v19.i2.a2

Supriyanto, S., Suripto, S., Sugiono, A., \& Sari, P. I. (2021). Impact of Oil Prices and Stock Returns: Evidence of Oil and Gas Mining Companies in Indonesia During the Covid-19 Period. International Journal of Energy Economics and Policy, 11(4), 312-318. https://doi.org/10.32479/ijeep.11290

Suripto, S. (2021a). Characteristics of banks as determinants of profit management for Islamic and conventional banks in ASEAN. Growing Science, 7, 1179-1188. https://doi.org/10.5267/j.ac.2021.2.020

Suripto, S. (2021b). The Effect of the COVID-19 Pandemic on Stock Prices with the Event Window Approach: A Case Study of State Gas Companies, in the Energy Sector. International Journal of Energy Economics and Policy, 11(3), 155-162. https://www.econjournals.com/index.php/ijeep/article/view/10999/5799

Suryani, AW, \& Rofida, E. (2020). Akuntansi Lingkungan dari Lensa Teori Sosiologi Kelembagaan Baru: Branding atau Tanggung Jawab? Jurnal Dinamika Akuntansi Dan Bisnis, 7(2), 189-204. https://doi.org/10.24815/jdab.v7i2.17126

Wardianto, KB, Damayanti, D., Destalia, M., \& Supriyanto, S. (2020). Strategi Meningkatkan

Ekuitas Merek di Indonesia. Jurnal Administrasi Bisnis, 9 (1), 15.https://doi.org/10.14710/jab.v9i1.26097

Widarjono, A. (2013). Pengenalan Ekonomis dan Penerapannya. Edisi ketiga. Yogyakarta: Ekonomi.

Wijayanti, DM, \& Yandra, FP (2020). Peran Insentif, Hubungan Emosional, dan Keadilan Organisasi dalam Membangun Sistem Pelaporan Pelanggaran yang Efektif: Studi Eksperimental. Jurnal Dinamika Akuntansi Dan Bisnis, 7(1), 51-68. https://doi.org/10.24815/jdab.v7i1.14178 